\title{
Increased susceptibility to OVX-associated metabolic dysfunction in UCP1-null mice
}

\author{
Stephanie L Clookey', Rebecca J Welly', Terese M Zidon', Michelle L Gastecki', Makenzie L Woodford', \\ Zachary I Grunewald1, Nathan C Winn', Dusti Eaton', Natalia G Karasseva², Harold S Sacks³, Jaume Padilla1,4,5 and \\ Victoria J Vieira-Potter ${ }^{1}$
}

\author{
1Department of Nutrition and Exercise Physiology, University of Missouri, Columbia, Missouri, USA \\ ${ }^{2}$ Transgenic Animal Core, University of Missouri, Columbia, Missouri, USA \\ ${ }^{3}$ Endocrine and Diabetes Division, Veterans Greater Los Angeles Healthcare System, Los Angeles, California, USA \\ ${ }^{4}$ Dalton Cardiovascular Research Center, University of Missouri, Columbia, Missouri, USA \\ ${ }^{5}$ Department of Child Health, University of Missouri, Columbia, Missouri, USA
}

Correspondence should be addressed to V J Vieira-Potter: vieirapotterv@missouri.edu

\begin{abstract}
Premenopausal females are protected against adipose tissue inflammation and insulin resistance, until loss of ovarian hormone production (e.g., menopause). There is some evidence that females have greater brown adipose tissue (BAT) thermogenic capacity. Because BAT mass correlates inversely with insulin resistance, we hypothesized that increased uncoupling protein 1 (UCP1) expression contributes to the superior metabolic health of females. Given that UCP1 transiently increases in BAT following ovariectomy (OVX), we hypothesized that UCP1 may 'buffer' OVX-mediated metabolic dysfunction. Accordingly, female UCP1-knockout (KO) and WT mice received OVX or sham (SHM) surgeries at 12 weeks of age creating four groups ( $n=10 /$ group), which were followed for 14 weeks and compared for body weight and adiposity, food intake, energy expenditure and spontaneous physical activity (metabolic chambers), insulin resistance (HOMA-IR, ADIPO-IR and glucose tolerance testing) and adipose tissue phenotype (histology, gene and protein expression). Two-way ANOVA was used to assess the main effects of genotype (G), OVX treatment (O) and genotype by treatment (GXO) interactions, which were considered significant when $P \leq 0.05$. UCP1KO mice experienced a more adverse metabolic response to OVX than WT. Whereas OVX-induced weight gain was not synergistically greater for KO compared to WT (GXO, NS), OVX-induced insulin resistance was significantly exacerbated in KO compared to WT (GXO for HOMA-IR, $P<0.05)$. These results suggest UCP1 is protective against metabolic dysfunction associated with loss of ovarian hormones and support the need for more research into therapeutics to selectively target UCP1 for prevention and treatment of metabolic dysfunction following ovarian hormone loss.
\end{abstract}

Journal of Endocrinology (2018) 239, 107-120

\section{Introduction}

Premenopausal females are protected against insulin resistance and adipose tissue inflammation, which are major independent predictors of metabolic disease
(Regensteiner et al. 2015). However, postmenopausal women exhibit a disproportionate acceleration in metabolic disease risk relative to males, characterized 
by increased accumulation of visceral adiposity and associated inflammation (Auro et al. 2014, Stefanska et al . 2015). Similarly, ovariectomized (OVX) rodents exhibit greater adipose tissue inflammation and systemic insulin resistance relative to ovary-intact controls (Nickelson et al. 2012, Pettersson et al. 2012, Vieira Potter et al. 2012), whereas estrogen $\left(\mathrm{E}_{2}\right)$ replacement therapy mitigates many of the adverse manifestations of ovarian hormone loss. Importantly, in light of the adverse side effects of $\mathrm{E}_{2}$ replacement therapy, alternative therapeutic approaches are warranted (Ouyang et al. 2006).

Adipose tissue health is a major predictor of metabolic disease. Indeed, white adipose tissue inflammation has been implicated as a causal link between obesity and cardiometabolic complications (Kanda et al. 2006, Ginsberg \& MacCallum 2009, Reaven 2011, Vieira-Potter 2014). However, brown adipose tissue (BAT) is metabolically protective, as its relative abundance and activity inversely associates with insulin resistance and type 2 diabetes (Manolopoulos et al. 2010, Ouellet et al. 2011). In this context, increased BAT activity has been shown to improve wholebody insulin sensitivity and glucose homeostasis in overweight adult humans (Chondronikola et al. 2014) and rodents (Stanford et al. 2012). Uncoupling protein 1 (UCP1) is the signature mitochondrial protein in BAT, which enables adaptive thermogenesis by uncoupling oxidative phosphorylation. There is evidence that UCP1 has a direct, insulin-sensitizing role, as overexpression of UCP1 protects against diet-induced obesity and insulin resistance in mice (Kopecky et al. 1996), and mice null for UCP1 are more susceptible to western diet (WD)-induced insulin resistance (Winn et al. 2017b). In considering that $\mathrm{E}_{2}$ has protective actions in adipose tissue, which may contribute to the metabolic protection observed in ovary-intact females, one hypothesis is that $\mathrm{UCP} 1$ may be regulated by $\mathrm{E}_{2}$, and this may help explain $\mathrm{E}_{2}$ 's protective effects in adipose tissue. This hypothesis originates from the observations of some investigators that ovary-intact females have more BAT than agematched males (Cypess et al. 2009, Pfannenberg et al. 2010) and/or are more sensitive to BAT activation (Quevedo et al. 1998, van den Beukel et al. 2015). It is also known that, on a gram per gram basis, white adipose tissue from females contributes more to resting energy expenditure compared to that from males; this suggests that female adipose tissue contains more UCP1 and/or greater mitochondrial density (Nookaew et al. 2013). Whether those sex differences are at least partially explained by $\mathrm{E}_{2}$ is not known. However, it is important to note that not all studies have supported that there is a sex difference in BAT content and/or activity (van der Lans et al. 2013). In fact, when we compared BAT UCP1 levels in male and female mice (housed under the same temperature conditions as the present study), we did not find an increase in UCP1 protein content (Winn et al. 2017a), although we did find greater UCP1 gene expression in females. Others have had similar findings in mice where no sex differences in BAT UCP1 content were found (Grefhorst et al. 2015). However, a large survey study of adult men and women showed that young women had higher probability of having detectable BAT by positron emission tomography (Wang et al. 2015). Furthermore, others have shown that this sex difference wanes with increasing age (Ouellet et al. 2011), which lends support to the hypothesis that $E_{2}$ availability contributes to the sex difference, since $\mathrm{E}_{2}$ declines with age in women. In fact, in high-fat diet-fed rodents, $\mathrm{E}_{2}$ treatment has been shown to increase UCP1 protein and other markers of adipose tissue browning (Al-Qahtani et al. 2017). Moreover, $\mathrm{E}_{2}$ signaling in the brain has been shown to increase BAT activation via the sympathetic nervous system (de Morentin et al. 2014). Taken together, those findings suggest that there may be sex differences in BAT content and/or susceptibility to its activation and these differences may be dependent on $\mathrm{E}_{2}$, the major sex hormone circulating in young women that falls considerably following menopause.

Somewhat paradoxically, OVX has been shown to increase UCP1 protein expression in BAT (Nadal-Casellas et al. 2011). Similarly, we have also observed an increase in BAT UCP1 following OVX in rodents (Vieira-Potter et al. 2015), similar to increases in UCP1 observed under conditions of diet-induced obesity (Feldmann et al. 2009, Cannon \& Nedergaard 2010, Yao et al. 2014, Sakamoto et al. 2016, Winn et al. 2017b). Those findings do not necessarily rule out the possibility that $\mathrm{E}_{2}$ regulates $\mathrm{UCP} 1$, since adipose tissue continues to produce $\mathrm{E}_{2}$ even following OVX or menopause via activity of aromatase, which may increase following menopause leading to increased local (i.e., adipose tissue) $\mathrm{E}_{2}$ exposure. The induction of UCP1 following OVX in BAT may also be triggered by metabolic stress (i.e., similar to high-fat diet-induced UCP1 induction) and completely independent of $\mathrm{E}_{2}$. Although this current study did not test those hypotheses (i.e., regarding $\mathrm{E}_{2}$ 's ability to regulate UCP1 or mechanisms by which OVX, at least transiently, increases UCP1 in BAT), we took the first step of testing the hypothesis that absence of UCP1 would exacerbate OVX-associated metabolic dysfunction and adipose tissue inflammation. 


\section{Methods}

\section{Ethical approval}

All animal husbandry and experimental procedures were carried out in accordance with the Association for Assessment and Accreditation of Laboratory Animal Care and approved by the University of Missouri Institutional Animal Care and Use Committee before their initiation.

\section{Animals and experimental design}

Heterozygote female UCP1-/+ mice on a C57BL/6J background were purchased from Jackson Laboratory (Stock \#003124) and bred at the University of Missouri Transgenic Animal Core (Columbia, MO, USA) facility to produce homozygote $\mathrm{UCP} 1^{-/-}$(UCP1KO; $n=20$ females) and littermate WT controls ( $n=20$ females). All mice were fed a standard chow diet $(3.3 \mathrm{kcal} / \mathrm{g}$ of food, $13 \% \mathrm{kcal}$ fat, $57 \% \mathrm{kcal}$ carbohydrate and 30\% kcal protein, 5001, LabDiet, St. Louis, MO, USA) and were housed two to three per cage (within group) in a light cycle from $07: 00$ to $19: 00 \mathrm{~h}$ at $25^{\circ} \mathrm{C}$. In previous studies, these conditions were shown to be adequate in preventing thermostress (Winn et al. 2017a). WT and UCP1KO female mice underwent OVX or sham (SHM) operations at 12 weeks of age creating four distinct groups ( $n=10$ /group): (1) WT SHM, (2) WT OVX, (3) KO SHM and (4) KO OVX. These animals were assessed for 14 weeks and compared for total and regional adiposity, indicators of adipose tissue inflammation and metabolism, systemic fuel metabolism and energy expenditure and insulin resistance. At 26 weeks of age, following a 5-hour fast, mice were killed and blood and tissues were collected. Tissues were harvested and either fixed in $10 \%$ formalin, snap-frozen in liquid nitrogen and stored at $-80^{\circ} \mathrm{C}$ until analyses. Data were generated from a subset of these animals in a previous study (Winn et al. 2017a).

\section{Body composition and tissue weights}

The percent body fat (BF\%) was measured by a nuclear magnetic resonance imaging whole-body composition analyzer (EchoMRI 4in1/1100; Echo Medical Systems, Houston, TX), 1 week prior to killing. Upon killing, interscapular BAT, thoracic periaortic BAT, subcutaneous (inguinal, SQAT) and visceral (perigonadal) white adipose tissue (PGAT) were extracted and tissue weights were collected.

\section{Energy expenditure assessment}

At 18 weeks of age, animals ( $n=10 /$ group) were placed in indirect calorimetry chambers (Promethion; Sable Systems International, Las Vegas, Nevada) to assess metabolic activity parameters including total energy expenditure, resting energy expenditure (REE) and spontaneous physical activity (SPA) by the summation of $x-, y$ - and $z$-axis beam breaks. Body weight and food intake were measured before and after each 48 -h assessment. Each 48-h run captured at least two light and two darkness cycles of REE.

\section{Fasting blood parameters}

Plasma glucose, cholesterol, triglycerides and nonesterified fatty acids (NEFA) assays were performed by a commercial laboratory (Comparative Clinical Pathology Services, Columbia, MO, USA) on an Olympus AU680 automated chemistry analyzer (Beckman-Coulter, Brea, CA, USA) using assays as per manufacturer's guidelines. Plasma insulin concentrations were determined using a commercially available, mouse-specific ELISA (Alpco Diagnostics, Salem, NH, USA). The homeostasis model assessment of insulin resistance (HOMA-IR) was used as a surrogate measure of hepatic insulin resistance ((fasting insulin $(\mu \mathrm{U} / \mathrm{L}) \times$ fasting glucose $(\mathrm{mg} / \mathrm{dL}) / 405.1)$ (Matthews et al. 1985)) and an index of adipose tissue insulin resistance (ADIPO-IR) was calculated as the product of fasting insulin $(\mu \mathrm{U} / \mathrm{L})$ and fasting NEFAs $(\mathrm{mmol} / \mathrm{L})$ (Lomonaco et al. 2012). Fasting levels of circulating adipokines, leptin and adiponectin, were measured using colorimetric ELISA (\#90030, \#80569, Crystal Chem) and data are presented as $\mu \mathrm{g} / \mathrm{mL}$.

\section{Histological assessments}

Formalin-fixed samples were processed through paraffin embedment, sectioned at $5 \mu \mathrm{m}$ and stained with hematoxylin and eosin (interscapular BAT, visceral white AT). Sections were evaluated via an Olympus BX34 photomicroscope (Olympus) and images were taken via an Olympus SC30 Optical Microscope Accessory CMOS color camera. Adipocyte size was calculated from three independent regions of the same $40 \times$ objective fields for PGAT and BAT depots (50 adipocytes/animal). Crosssectional areas of the adipocytes were obtained from perimeter tracings using Image software as previously described (Wainright et al. 2015). An investigator blinded to the groups performed all procedures. 


\section{RNA extraction and quantitative real-time RT-PCR}

Interscapular BAT, PGAT and SQAT samples were homogenized in TRIzol solution using a tissue homogenizer (TissueLyser LT, Qiagen). Total RNA was isolated according to the Qiagen's RNeasy lipid tissue protocol and assayed using a Nanodrop spectrophotometer (Thermo Scientific) to assess the purity and concentration. First-strand cDNA was synthesized from total RNA using the High Capacity cDNA Reverse Transcription kit (Applied Biosystems). Quantitative real-time PCR was performed as previously described using the ABI StepOne Plus sequence detection system (Applied Biosystems) (Roseguini et al. 2010, Padilla et al. 2013). Primer sequences were designed using the NCBI Primer Design tool. All primers were purchased from IDT (Coralville, IA, USA). The beta actin gene (Actb) was used as house-keeping control gene. Actb cycle threshold (CT) was not different among the groups of animals. mRNA expression was calculated by $2^{\Delta \mathrm{CT}}$ where $\Delta \mathrm{CT}=A c t b$ CT - gene of interest CT and presented as fold-difference. mRNA levels were normalized to the of WT SHM group which was set at 1 .

\section{Western blotting}

Protein content was measured as previously described

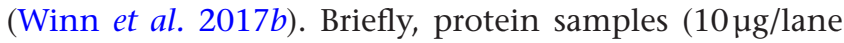
were separated by SDS-PAGE, transferred to polyvinylidene difluoride membranes and probed with primary antibodies, including UCP1 (\#U6382, 1:1000; Sigma-Aldrich), UCP2 (\#89326, 1:1000; Cell Signaling), Acetyl Co-A Carboxylase or ACC (\#3662, 1:1000, Cell Signaling), Phosphorylated Acc or PACC(\#3661, 1:1000 Cell Signaling), OXPHOS (\#M5604, 1:1000, MitoSciences), Ampk (\#2532, 1:1000, Cell Signaling), AMPK-SER485 (4185, 1:1000, Cell Signaling), AMPK-THR172 (\#2531, 1:1000, Cell Signaling), Estrogen Receptor Alpha (Yasrebi et al. 2016) (\#75635, 1:1000, Abcam), Estrogen Receptor Beta (ERB) (\#AB3577, 1:2000, Abcam), GLUTIV (\#2213, 1:1000, Cell Signaling), AKT (\#4691, 1:500, Cell Signaling). Intensity of individual protein bands was quantified using FluoroChem HD2 (AlphaView, version 3.4.0.0) and expressed as ratio to Amide Black total protein stain.

\section{Statistical analysis}

A $2 \times 2$ ANOVA was used to evaluate the effects of genotype (UCP1KO vs WT, denoted by G) and treatment (OVX vs SHM, denoted by O) and genotype by treatment interactions (denoted by $\mathrm{GxO}$ ). When significant interactions were observed, Tukey's post hoc tests were used to indicate significant between-group differences (* used to denote such differences). All data are presented as mean \pm standard error of the mean (s.E.M.). For all statistical tests, significance was accepted at $P \leq 0.05$. All statistical analyses were performed using SPSS V20.0.

\section{Results}

\section{Effects of UCP1 ablation and OVX on adiposity}

Main effects of both genotype (i.e., UCP1KO) and OVX were found for body weight gain from baseline (Fig. 1A) and final body weight (Fig. 1B), body fat percentage (Fig. 1C), total fat mass (Fig. 1D), and white adipose tissue depot weights (Fig. 1E; all $P<0.05$ ). Total lean mass (Fig. 1D) and BAT mass (Fig. 1E) were greater in UCP1KO animals but not affected by OVX. However, UCP1KO animals tended to be more susceptible to an OVX-induced increase in periaortic BAT ( $\mathrm{GxO}, P=0.056)$. No significant GXO interactions were observed in assessments of weight gain. Actual body weight changes throughout the study for all groups is provided in Supplementary Fig. 1A (see section on supplementary data given at the end of this article).

\section{Effects of UCP1 ablation and OVX on energy expenditure and SPA}

Both KO genotype and OVX reduced total and REE relative to body weight $(\mathrm{G}, \mathrm{O}$, both $P \leq 0.05)$ (Fig. $2 \mathrm{~A}$ and $\mathrm{C})$. In the dark cycle (i.e., rodent active period), OVX reduced cage physical activity $(\mathrm{O}, \mathrm{P}<0.001)$, recapitulating findings that loss of ovarian hormones reduces voluntary physical activity (Park et al. 2016); no effect of UCP1 ablation on cage physical activity was observed (Fig. 2B). While UCP1KO animals consumed significantly less energy than WT (Fig. 2D; G, $P=0.003$ ), both genotypes reduced their food intake under conditions of $\operatorname{OVX}(\mathrm{O}, P<0.001)$. Likewise, metabolic efficiency was greater in UCP1KO vs. WT animals and was also increased by OVX in both genotypes $(\mathrm{G}, \mathrm{O}$, both $P<0.05)$ (Fig. $2 \mathrm{E}$ ).

\section{Effects of UCP1 ablation and OVX on glucose and lipid metabolism}

While there were no statistically significant differences in glucose tolerance across groups (Fig. 3A), KO animals were hyperinsulinemic compared to WT $(\mathrm{G}, P<0.001)$ 
A

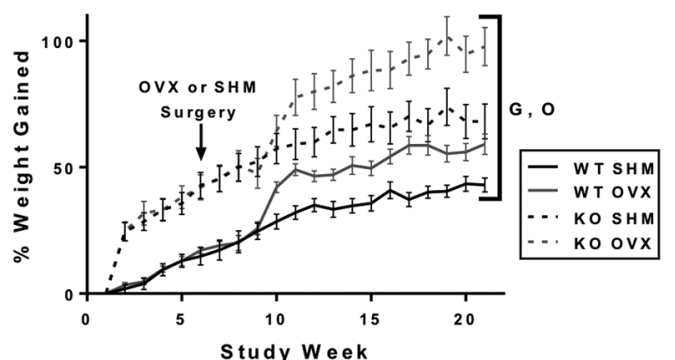

B

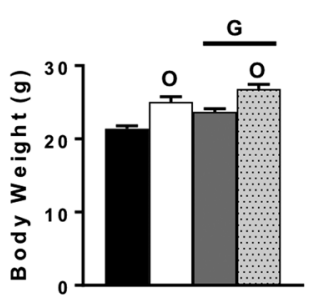

C

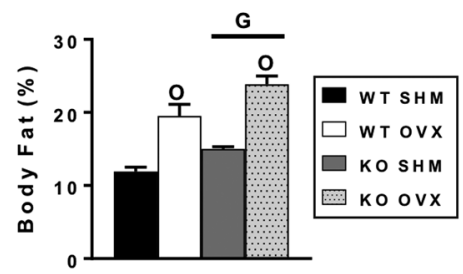

D

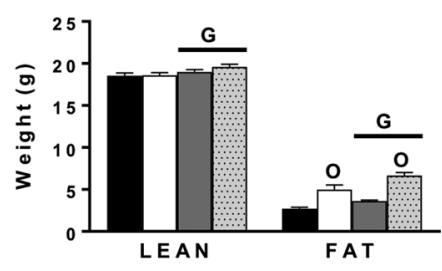

E

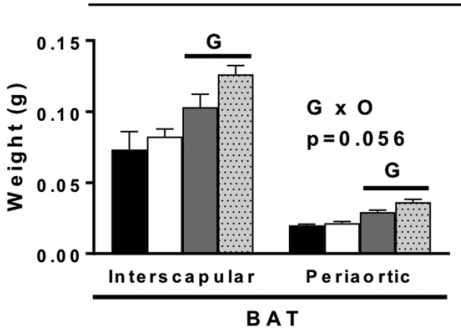

Fat pad mass

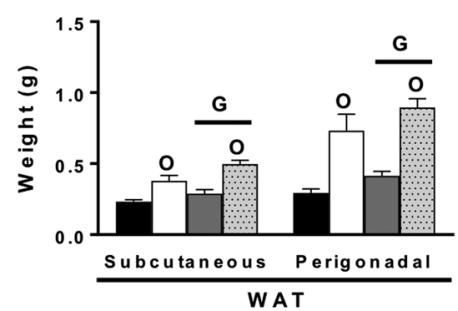

\section{Figure 1}

Influence of UCP1 ablation and OVX on \% weight gained, body weight, and adiposity. UCP1-null and WT female mice were subject to ovariectomy or sham surgery at 12 weeks of age, then assessed for 14 weeks for: (A) \% body weight gained from baseline; (B) body weight; (C) body fat percentage; (D) body composition; (E) fat pad mass. KO, UCP1 knockout; SHM, sham surgery; OVX, ovariectomy; $2 \times 2$ analysis of variance (ANOVA) was performed to assess main effects of genotype $(\mathrm{G})$, ovariectomy $(\mathrm{O})$, and genotype and ovariectomy interactions (GxO). GxO were followed by Tukey's post hoc tests. Where such tests revealed significant differences between groups, those differences are indicated. Data are expressed as means \pm standard error (s.E.); $n=10 /$ group, significance was accepted at $P<0.05$.

Total Energy Expenditure

A

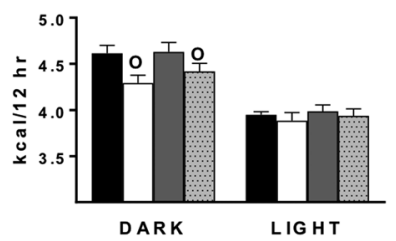

Resting Energy Expenditure

C

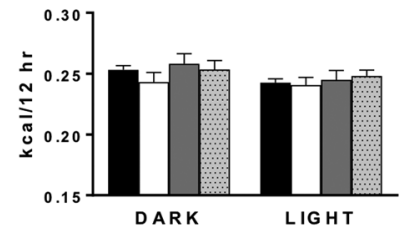

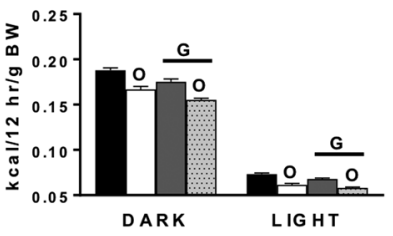

IG HT

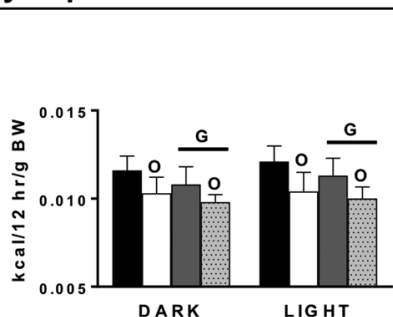

\section{Spontaneous Physical Activity}

B

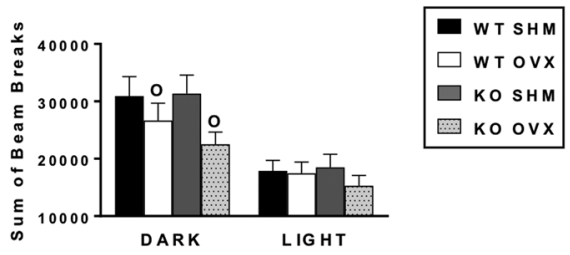

Energy Intake
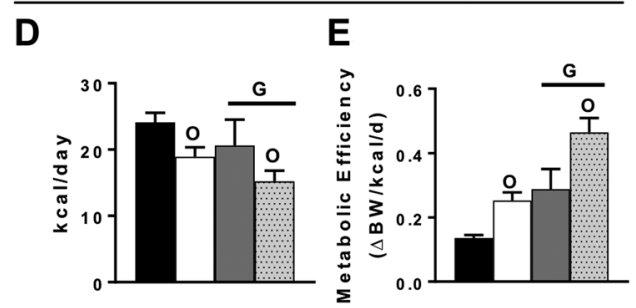

Figure 2

Influence of UCP1 ablation and OVX on energy expenditure, spontaneous physcial activity and energy intake. UCP1-null and WT female mice were subject an ovariectomy or sham surgery at 12 weeks of age, then placed in indirect calorimetry chambers and assessed for metabolic activity parameters: (A) total energy expenditure; (B) spontaneous physical activity; (C) resting energy expenditure; (D) energy intake; (E) metabolic efficiency. KO, UCP1 knockout; SHM, sham surgery; OVX, ovariectomy; $2 \times 2$ analysis of variance (ANOVA) was performed to assess main effects of genotype (G), ovariectomy $(\mathrm{O})$, and genotype and ovariectomy interactions ( $\mathrm{GxO}$ ). GxO were followed by Tukey's post hoc tests. Where such tests revealed significant differences between groups, those differences are indicated. Data are expressed as means \pm standard error (s.E.); $n=10 /$ group, significance was accepted at $P<0.05$. 


\begin{tabular}{l|l|l|l|l|}
$\begin{array}{l}\text { Journal of } \\
\text { Endocrinology }\end{array}$ & SLClookey et al. & $\begin{array}{l}\text { UCP1 knockout in response } \\
\text { to OVX }\end{array}$ & $\mathbf{2 3 9 : 2}$ & $\mathbf{1 1 2}$ \\
\hline
\end{tabular}
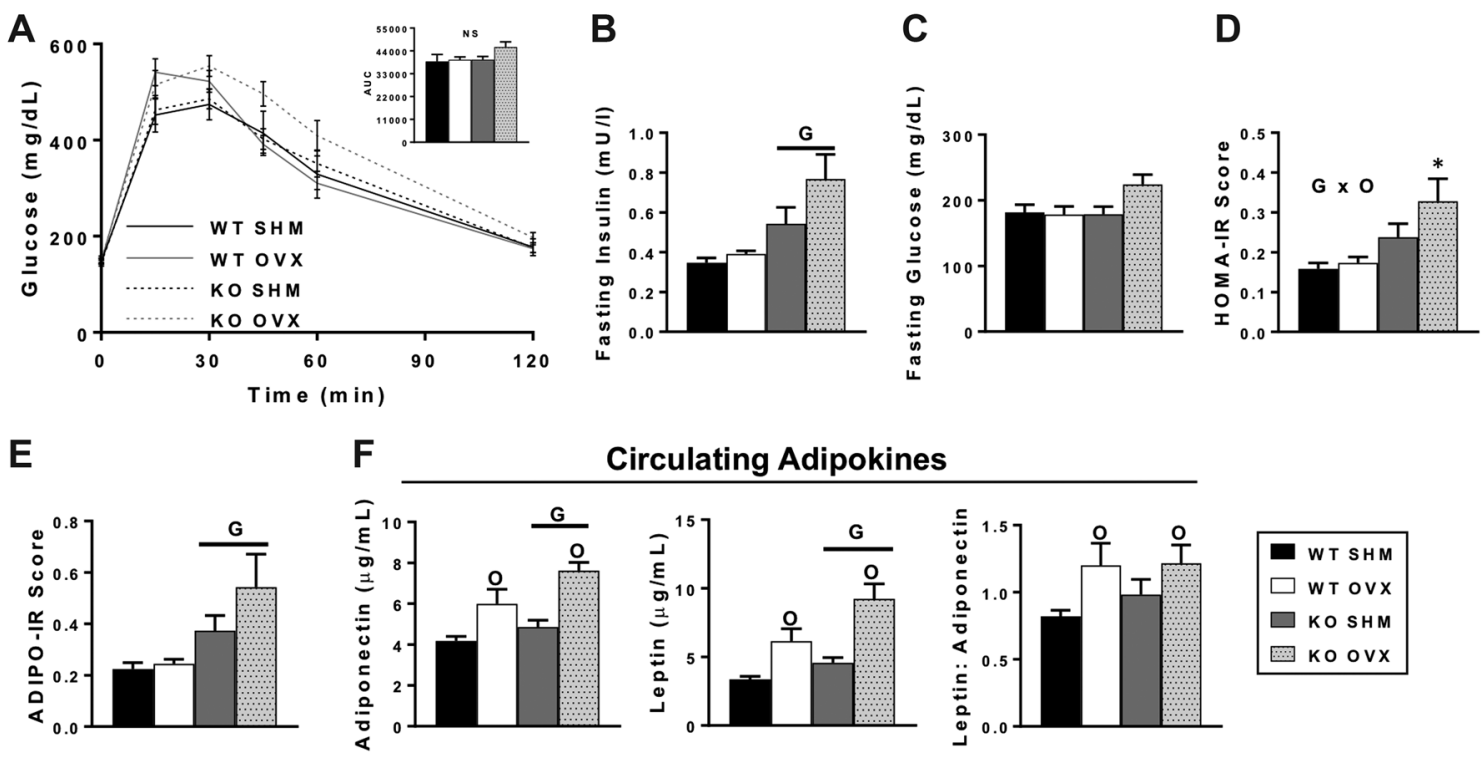

Circulating Adipokines

Figure 3

Influence of UCP1 ablation and OVX on glucose metabolism in female mice. UCP1-null and WT female mice were subject to an ovariectomy or sham surgery, then administered a glucose tolerance test 12 weeks post-surgery: (A) glucose tolerance test and area under the curve (AUC); (B) fasting insulin; (C) fasting glucose; (D) homeostasis model of assessment of insulin resistance (HOMA-IR); (E) adipose tissue insulin resistance (ADIPO-IR); (F) circulating adiponectin; (G) circulating leptin; (I) leptin:adiponectin ratio. KO, UCP1 knockout; SHM, sham surgery; OVX, ovariectomy; $2 \times 2$ analysis of variance (ANOVA) was performed to assess main effects of genotype (G), ovariectomy $(\mathrm{O})$, and genotype and ovariectomy interactions (GxO). GxO were followed by Tukey's post hoc tests. Where such tests revealed significant differences between groups, those differences are indicated; $* P<0.05$ compared to all other groups. Data are expressed as means \pm standard error (S.E.); $n=10 /$ group, significance was accepted at $P<0.05$.

(Fig. 3B). Moreover, systemic UCP1 ablation exacerbated OVX-induced increase in HOMA-IR (GxO, P=0.049) resulting in the KO/OVX group having higher HOMA-IR values than all other groups (Fig. 3D). There was no main effect of OVX on ADIPO-IR; however, this measure was significantly greater in UCP1KO animals (Fig. 3E). Plasma levels of the adipokines, adiponectin and leptin were also measured, as their circulating levels can be indicative of systemic insulin sensitivity. Adiponectin is generally associated with enhanced insulin sensitivity, while leptin is generally secreted in proportion to adiposity; thus, the leptin:adiponectin ratio is used here as a systemic correlate of adipocyte insulin resistance. Here, plasma levels of both adipokines were increased by OVX and also were higher in KO compared to WT animals (G, $\mathrm{O}$, both $\mathrm{P}<0.05$ ) (Fig. 3F). However, a higher leptin:adiponectin ratio was driven by OVX, yet not affected by UCP1 ablation $(\mathrm{O}, P \leq 0.05)$. There were no significant differences in fasting NEFAs, LDL or triglyceride levels yet UCP1KO had lower total and HDL cholesterol levels relative to WT controls. However, OVX increased total and HDL cholesterol in the UCP1KO animals and tended to have the opposite effect in the WT (Table 1).

Table 1 Blood biochemistry in fasted female WT and UCP1 knockout mice under ovary-intact and ovariectomized conditions.

\begin{tabular}{|c|c|c|}
\hline \multirow[b]{2}{*}{ Variable } & \multicolumn{2}{|c|}{ WT } \\
\hline & SHM & OVX \\
\hline NEFA (mmol/L) & $0.64 \pm 0.05$ & $0.63 \pm 0.04$ \\
\hline TG $(\mathrm{mg} / \mathrm{dL})$ & $134.60 \pm 8.80$ & $136.00 \pm 5.90$ \\
\hline LDL (mg/dL) & $3.63 \pm 0.34$ & $3.54 \pm 0.28$ \\
\hline $\mathrm{HDL}(\mathrm{mg} / \mathrm{dL})$ & $28.50 \pm 1.00^{\#}$ & $25.80 \pm 1.10$ \\
\hline Cholesterol (mg/dL) & $50.50 \pm 1.50$ & $45.40 \pm 1.70$ \\
\hline
\end{tabular}

\begin{tabular}{|c|c|c|}
\hline \multicolumn{2}{|c|}{ ко } & \multirow[b]{2}{*}{ P-Value } \\
\hline SHM & OVX & \\
\hline $0.69 \pm 0.05$ & $0.66 \pm 0.05$ & NS \\
\hline $131.00 \pm 4.30$ & $130.60 \pm 6.10$ & NS \\
\hline $3.00 \pm 0.15$ & $3.40 \pm 0.27$ & NS \\
\hline $22.90 \pm 1.20$ & $28.90 \pm 2.00^{\#}$ & $\mathrm{GxO}$ \\
\hline $41.10 \pm 2.00$ & $52.90 \pm 2.90^{\#}$ & $\mathrm{GxO}$ \\
\hline
\end{tabular}

All data expressed as mean \pm S.E.; $n=10 /$ group.

$\# P<0.05$ compared to KO SHM via post hoc Tukey's test.

G, $P<0.05$ main effect of genotype; GxO, $P<0.05$ interaction between $\mathrm{G}$ and $\mathrm{O} ; \mathrm{KO}$, UCP1 knockout; NEFA, non-esterified fatty acids; NS, no significant differences detected; $O, P<0.05$ main effect of ovariectomy; OVX, ovariectomized condition; SHM, sham/ovary-intact condition; TG, triglycerides. 


\section{Effects of UCP1 ablation and OVX on BAT phenotype}

Under the non-cold stressed conditions of this study, BAT phenotype was at most modestly affected based on histological analysis (Fig. 4A). UCP1 ablation did increase mean brown adipocyte size $(G, P<0.05)$; however, this measure was not affected by OVX (Fig. 4D). Analysis of gene expression revealed a genotype effect for an increase in the marker of mitochondrial biogenesis, mitochondrial transcription factor A (Tfam), as well as seven-fold increases in DNA damage-inducible transcript 3 (Ddit3) and fibroblast growth factor 1 (Fgf21) (indicators of endoplasmic reticulum (ER)/oxidative stress) in UCP1KO mice (Fig. 4B). All primer sequences are provided in Table 2. UCP1KO also had increased gene expression of $\mathrm{E}_{2}$ receptor beta (Esr2) in BAT, whereas Esr1 expression was not affected. OVX induced a decrease in glutathione peroxidase (Gpx3), an $\mathrm{E}_{2}$-regulated protein that functions to detoxify hydrogen peroxide (Lundholm et al. 2008) and increased expression of the adipokines leptin (Lep) and adiponectin (Adipoq). In the case of $G p \times 3$, the OVX-induced reduction was more severe in the $\mathrm{UCP} 1 \mathrm{KO}$, indicated by the significant GXO interaction.
Gene expression analysis of uncoupling protein 2 (Ucp2), another uncoupling protein known to be upregulated by $\mathrm{E}_{2}$ (Pedersen et al. 2001), revealed a GxO interaction in that UCP1 ablation increased, whereas OVX decreased, its expression ( $\mathrm{GxO}, P \leq 0.05)$. Lipocalin (Lcn2), an adipokine thought to regulate $E_{2}$ signaling in adipose tissue (Drew et al. 2015), was diminished in UCP1KO mice and further reduced by $\operatorname{OVX}(\mathrm{G}, \mathrm{O}$, both $P<0.05)$. There was no evidence of increased inflammatory gene expression in BAT.

Recapitulating what we have previously reported in other studies comparing UCP1KO and WT mice, we observed a decrease in the mitochondrial oxidative phosphorylation proteins, cytochrome $\mathrm{C}$ oxidase enzyme complex (COX) 1, 2, 3 and 4 were observed (Fig. 4C and $\mathrm{E}$ ). However, there was no evidence for changes in protein expression relevant to energy regulation, such as AMPK phosphorylation at either the Serine-491/485 (i.e., inhibitory) or Threonine-179 (i.e., activation) sites or phosphorylated acetyl-CoA carboxylase (Gambacciani et al. 1997) relative to total ACC protein, which catalyzes the committed step in fatty acid synthesis $(G, P \leq 0.05)$. To explore potential interactions between $E_{2}$ signaling

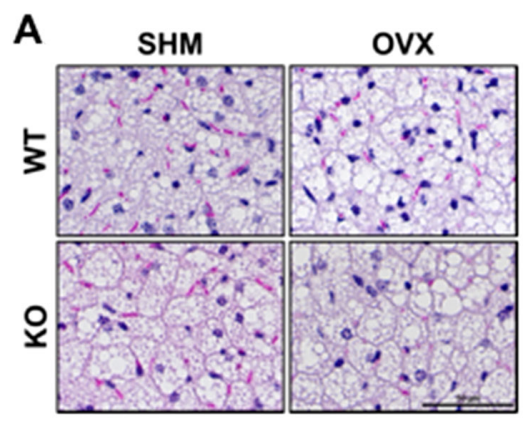

B

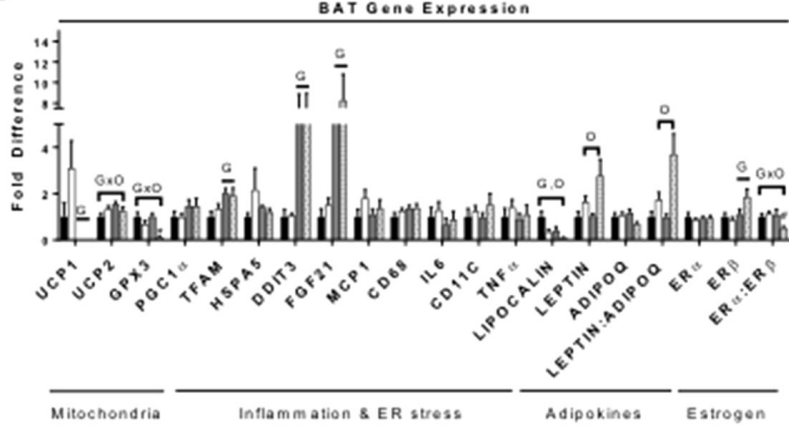

D

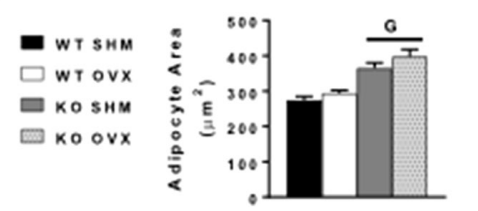

E

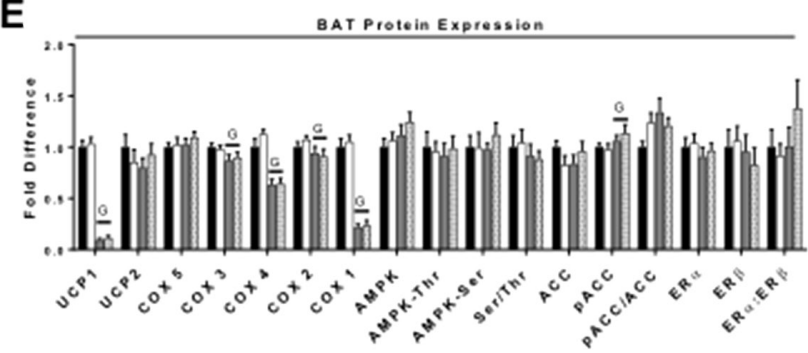

C

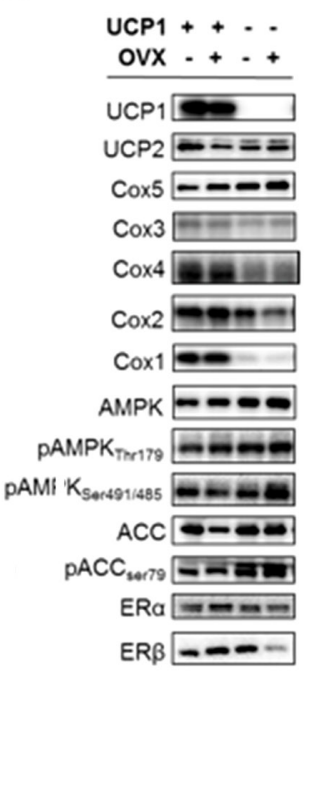

Figure 4

Influence of UCP1 ablation and OVX on brown adipose tissue phenotype and immunometabolism. UCP1-null and WT female mice were subject to an ovariectomy or sham surgery at 12 weeks of age, then sacrificed after 14 weeks. Brown adipose tissue samples were collected to assess phenotype, gene expression and protein content: (A) interscapular brown adipose tissue histology; (B) brown gene expression; (C) Western blot representative images; (D) brown adipocyte size; (E) protein expression. KO, UCP1 knockout; SHM, sham surgery; OVX, ovariectomy; $2 \times 2$ analysis of variance (ANOVA) was performed to assess main effects of genotype (G), ovariectomy (O), and genotype and ovariectomy interactions (GxO). GxO were followed by Tukey's post hoc tests. Where such tests revealed significant differences between groups, those differences are indicated. Data are expressed as means \pm standard error (s.E.); $n=10 /$ group, significance was accepted at $P<0.05$. 
Table 2 Primer sequences used to determine adipose tissue gene expression in mice.

\begin{tabular}{l} 
Gene \\
\hline Ucp1 \\
Ucp2 \\
Gpx3 \\
Pgc1a \\
Tfam \\
Mcp1 \\
Cd68 \\
IL-6 \\
Cd11c \\
Tnfa \\
Hspa5 \\
Ddit3 \\
Leptin \\
Adipoq \\
Fgf21 \\
Lcn2 \\
Cyp19a1 \\
Esr1 \\
Esr2 \\
Actb
\end{tabular}

Forward
ACTGCCACACCTCCAGTCATT
AAG TGTTTCGTCTCCCAGCC
GTATGGAGCCTCACCATCG
CCCTGCCATTGTTAAGACC
GAGCGTGCTAAAAGCACTGG
GGCTGGAGAGCTACAAGAGG
TGTTCAGCTCCAAGCCCAAA
TCCAGTTGCCTTCTTGGGAC
ATGCCACTGTCTGGCTTCAT
CTATGTCTCAGCCTCTTCTC
TGTGTGTGAGACCAGAACCG
ATGTTGAAGATGAGCGGGTG
CCTATTGATGGGTCTGCCCG
GCACTGGCAAGTTCTACTGCAGCAA
GTACCTCTACACAGATGACGACCAA
ATATGCACAGGTATCCTCAG
AACATCATTCTGAACATCGG
AAGACGCTCTTGAACCAGCA
GCATTGCCTGAACAAAGCCA
GATGTATGAAGGCTTTGGTC

\begin{tabular}{l} 
Reverse \\
\hline CTTTGCCTCACTCAGGATTGG \\
CTAGCCCTTGACTCTCCCCT \\
GCTCTTTCTCCCCGTTCACA \\
TGCTGCTGTTCCTGTTTTC \\
CCACAGGGCTGCAATTTTCC \\
GGTCAGCACAGACCTCTCTC \\
GTACCGTCACAACCTCCCTG \\
AGTCTCCTCTCCGGACTTGT \\
GAGCCAGGTCAAAGGTGACA \\
CATTTGGGAAACTTCTCATCC \\
GCAGTCAGGCAGGAGTCTTA \\
TGGAACACTCTCTCCTCAGGT \\
TGAGCGCTACCTGCATAGAC \\
GTAGGTGAAGAGAACGGCCTTGT \\
CGCCTACCACTGTTCCATCCT \\
GAAACGTTCCTTCAGTTCAG \\
AGGGAACATTCTTCTCAAAG \\
TCTCCAGGTAGTAGGGCACC \\
TTGGGACAGCACTCTTCGTC \\
TGTGCACTTTTATTGGTCTC
\end{tabular}

Gene names: Ucp1, uncoupling protein 1; Ucp2, uncoupling protein 2; Gpx3, glutathione peroxidase; Pgc1a, peroxisome proliferator-activated receptor-gamma coactivator 1-alpha; Tfam, mitochondrial transcription factor a; Mcp 1, monocyte chemoattractant protein 1; Cd68, cluster of differentiation 68; II-6, interleukin 6; Cd11c, cluster of differentiation 11c; Tnfa, tumor necrosis factor alpha; Hspa5, heat shock protein family A member 5; Ddit3, DNA damage-inducible transcript 3 protein; Adipoq, adiponectin; Fgf21, fibroblast growth factor 21; Lcn2, lipocalin 2; Cyp19a1, aromatase, Esr1, estrogen receptor alpha; Esr2, estrogen receptor beta; Actb, beta actin.

proteins and UCP1 (Frank et al. 2017), we also measured levels of $\mathrm{E}_{2}$ receptor alpha (Yasrebi et al. 2016) and beta (ERB). Here, we did not find significant differences in ERa or ERB protein content in BAT with either UCP1 ablation or OVX, and there was no difference between groups in the ratio of ERa:ERB protein expression, a ratio that has been shown to correlate positively with a 'healthy' adipose tissue phenotype (Gao \& Dahlman-Wright 2013) and $\mathrm{E}_{2^{-}}$ mediated improvements in insulin sensitivity (Park et al. 2017) (Fig. 4C and E).

\section{Effects of UCP1 ablation and OVX on WAT phenotype}

OVX significantly increased PGAT (i.e., a WAT depot from the visceral region in the rodent) adipocyte size (Fig. 5A and D). In investigating gene expression in this WAT depot, OVX increased both Ddit 3 and $F g f 21$ in each genotype $(\mathrm{O}, \mathrm{P} \leq 0.05)$, indicative of increased cellular stress. Similar to previous findings in mice (Rogers et al. 2009, Vieira Potter et al. 2012), the PGAT depot also exhibited evidence of OVX-induced inflammation, indicated by increased gene expression of Mcp1, Il6, Tnfa, Cd68 and $C d c 11 c(\mathrm{O}$, all $P \leq 0.05)$ (Fig. 5B). Unlike BAT, UCP1 ablation only modestly increased inflammation as indicated by greater $C d 68$ gene expression relative to

$\begin{array}{lr}\text { https://joe.bioscientifica.com } & \text { ○ } 2018 \text { Society for Endocrinology } \\ \text { https://doi.org/10.1530/JOE-18-0139 } & \text { Published by Bioscientifica Ltd. } \\ \text { Printed in Great Britain }\end{array}$

WT $(G, P<0.05)$ with no other significant differences in inflammatory genes. Similar to BAT, OVX increased gene expression of Leptin, consistent with the phenotype of OVX-mediated adipocyte hypertrophy (Fig. 5D). In terms of GxO interactions, $U c p 2$ gene expression increased with OVX in WT, but not in the UCP1KO $(\mathrm{GxO}, P<0.05)$. On the contrary, Pgc1a increased with OVX only in the KO (GxO, $P \leq 0.05)$; similarly, $\mathrm{E}_{2}$ receptor alpha (Esr1) expression increased following OVX only in the $\mathrm{KO}(\mathrm{GxO}$, $P \leq 0.05)$.

In terms of protein expression, UCP1 ablation unexpectedly increased the mitochondrial subunit COX3 (G, $P \leq 0.05$ ) but did not affect any other proteins in PGAT. On the other hand, OVX resulted in an increase in COX 5 (i.e., ATP synthase enzyme), and a decrease in COX 1, total ACC and phosphorylated ACC (pACC, the active form of the enzyme). OVX also increased the amount of pACC relative to total ACC (Fig. 5E). Since emerging evidence suggests potential cross-talk between ER signaling and proteins associated with white adipocyte browning (Grefhorst et al. 2015, Qian et al. 2016), ERs were also quantified in this depot. In this regard, there were no significant differences in Era or ERB protein expression (Fig. 5C and E). The reason we chose to comprehensively assess the phenotype of PGAT is that this depot is most susceptible to metabolic inflammation and, in females, 


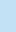
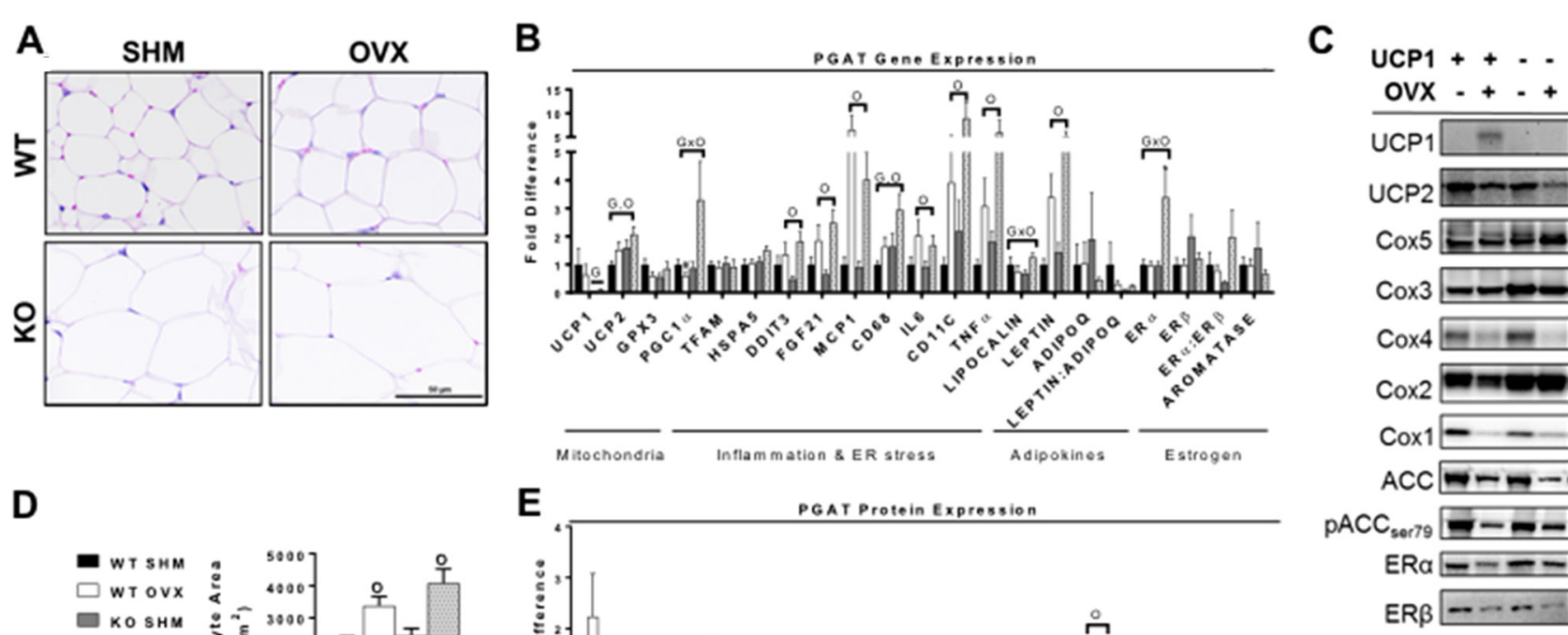

B

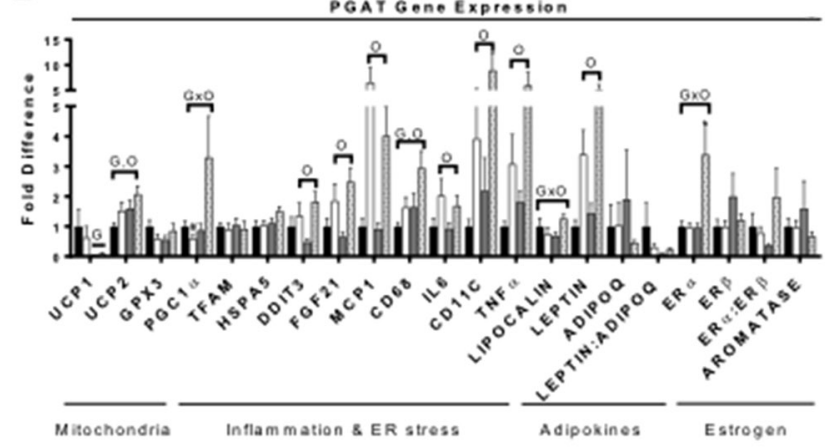

D
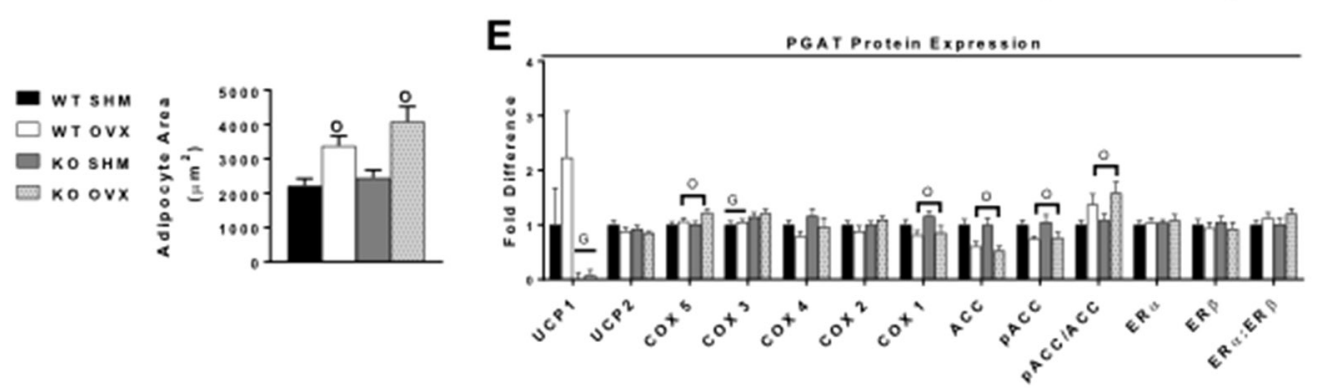

$E R \beta \ldots \ldots$

Figure 5

Influence of UCP1 ablation and OVX on perigonadal adipose tissue immunometabolism in female mice. UCP1-null and WT female mice were subject to an ovariectomy or sham surgery at 12 weeks of age, then sacrificed after 14 weeks. Perigonadal adipose tissue was harvested and processed for adipocyte size, gene expression and protein content: (A) perigonadal adipose tissue (PGAT) histology; (B) perigonadal gene expression; (C) western blot representative images; (D) perigonadal adipocyte size; (E) protein expression. KO, UCP1 knockout; SHM, sham surgery; OVX, ovariectomy; $2 \times 2$ analysis of variance (ANOVA) was performed to assess main effects of genotype (G), treatment (O), and genotype and treatment interactions (GXO). GXO were followed by Tukey's post hoc tests. Where such tests revealed significant differences between groups, those differences are indicated. Data are expressed as means \pm standard error (S.E.); $n=10 /$ group, significance was accepted at $P<0.05$.

this depot (proximal to the uterus) may actually be more susceptible to browning (Gonçalves et al. 2017). However, inguinal SQAT is the depot most classically thought to be associated with browning in rodents (Waldén et al. 2011). Moreover, recent work showed that this depot is susceptible to induction of thermogenesis and its associated improvements in glucose homeostasis, independent of UCP1 (Ikeda et al. 2017). Thus, we also assessed gene expression in the SQAT depot and provide those data in Supplementary Fig. 1B. Here, the findings were similar to the PGAT depot, that is, we confirmed previous findings that OVX increases WAT inflammation (e.g., increased gene expression of Il6, Tnfa, leptin) and decreases Gpx3. Also in line with what was observed in the PGAT depot in this study as well as in previous studies, loss of UCP1 increased Cdc11c expression.

\section{Discussion}

We sought to investigate if UCP1 plays a compensatory role in response to the metabolic dysfunction associated with ovarian hormone loss via ovariectomy (OVX) in

\begin{tabular}{|l} 
https://joe.bioscientifica.com \\
https://doi.org/10.1530/JOE-18-0139 2018 Society for Endocrinology \\
Published by Bioscientifica Ltd. \\
Printed in Great Britain
\end{tabular}

mice. It has been observed that UCP1 is upregulated in response to metabolic stress, such as diet-induced obesity (Feldmann et al. 2009, Cannon \& Nedergaard 2010, Yao et al. 2014, Sakamoto et al. 2016, Winn et al. 2017b) and OVX (Feldmann et al. 2009, Cannon \& Nedergaard 2010, Crissey et al. 2014, Vieira-Potter et al. 2015). This seemingly compensatory upregulation of UCP1 led us to hypothesize that lack of UCP1 would aggravate OVXinduced metabolic dysfunction. Consistent with this idea, we found that the absence of UCP1 worsened OVXmediated impairment in glucose metabolism, indicated by HOMA-IR scores and hyperinsulinemia. This supports the hypothesis that UCP1 upregulation following loss of ovarian hormones may mitigate metabolic dysfunction. Further, these data also support the contention that more total and/or active BAT (Cypess et al. 2009), or greater UCP1 expression, in premenopausal women compared to agematched men and older women (Pfannenberg et al. 2010) may contribute to their metabolic protection. It should be noted that the degree of insulin resistance observed here was very modest, as neither OVX nor UCP1 ablation caused glucose intolerance. This is probably because the mice tested here were young, relatively healthy females, 
known to exhibit metabolic protection. In addition, they were not under conditions of dietary stress, as they were fed a normal chow diet. Thus, despite either not expressing the protective protein, UCP1 or undergoing OVX, these mice remained relatively healthy. However, the combination of UCP1 ablation and OVX did result in a significantly worse metabolic phenotype compared to either treatment alone. Likely, OVX and UCP1 ablationinduced compensatory hyperinsulinemia resulting in apparently normal glucose tolerance test results. Future studies should employ the hyperinsulinemic-euglycemic clamp to most accurately assess insulin resistance and determine tissue-specific insulin sensitivity. Future studies should consider waiting longer for insulin resistance to develop, using older mice, challenging these groups with high-fat diet or measuring the insulin secretion response to glucose. Importantly, these current results taken together corroborate our previous findings (Winn et al. 2017b) and suggest that UCP1 improves insulin sensitivity via a mechanism independent of increased energy expenditure or fat loss.

Adipose tissue phenotype plays an important role in determining whole-body insulin sensitivity (Manolopoulos et al. 2010). This is particularly important for females who have greater adiposity and less lean mass compared to males. Importantly, while estrogen $\left(\mathrm{E}_{2}\right)$ drives fat storage in adipose tissue, it has many metabolically protective effects resulting in greater insulin sensitivity in $\mathrm{E}_{2}$-sufficient females, despite their greater adiposity. However, loss of ovarian hormone production, as occurs in natural or surgical menopause, abruptly dissolves this protection, increasing metabolic disease risk (Auro et al. 2014, Stefanska et al. 2015). Similarly, UCP1 ablation induces obesity and enhances metabolic efficiency (Feldmann et al. 2009). We observed that both UCP1 ablation and OVX led to increased body weight, largely attributed to adiposity, indicated by both greater body fat percentage and adipose tissue pad weights across several depots. Those changes in body mass due to both OVX and the UCP1KO genotype were accompanied by decreases in both food intake and REE, indicating that reduced basal metabolism, and not increased food intake or decreased physical activity, caused the energy surplus that led to the increased adiposity. This is somewhat unlike our previous study, where similarly aged UCP1KO and WT females did not differ in body weight. Other studies have demonstrated that UCP1KO mice only experience enhanced susceptibility to obesity under thermoneutral conditions, thought to be $\sim 30^{\circ} \mathrm{C}$. This has been hypothesized to be driven largely by loss of diet-induced thermogenesis in UCP1KO at thermoneutral conditions, whereas under cold stress, UCPKO animals utilize other means to regulate body temperature and energy balance (e.g., increased shivering and/or cage physical activity). Thus, it is possible that the mice in our present study were exposed to a warmer temperature than those in our first study. Although we set the temperature at $25^{\circ} \mathrm{C}$ for both studies, it is possible that room conditions (e.g., animals housed on higher shelves in the later study, which would contribute to slightly higher temperature) contributed to those differences. Importantly, in both our previous study and in the current study, UCP1 ablation disrupted glucose homeostasis, suggesting that UCP1 has insulin-sensitizing effects that can be dissociated from its ability to reduce adiposity. Supporting that idea, the UCP1KO animals in the current study were more susceptible to OVX-induced impairment in glucose homeostasis yet did not necessarily experience an enhancement in OVX-induced weight gain. That is, while the KO/OVX animals were heavier than either the $\mathrm{KO} / \mathrm{SHM}$ or WT/OVX, the effects were additive yet not synergistic (i.e., demonstrated statistically by main effects of genotype and OVX, but no significant interaction). However, HOMA-IR calculations did reveal a significant interaction between genotype and OVX, with UCP1KO/OVX animals having higher scores than all other groups. HOMA-IR is a proxy measure of insulin sensitivity, which correlates very strongly with direct measures of insulin tolerance (Antunes et al. 2016). We also observed UCP1 ablation-induced increases in ADIPO-IR scores, indicating increased adipose tissue insulin resistance. Our observations support previous findings, which illustrated a direct relationship between UCP1 expression and insulin sensitivity (Poher et al. 2015). Although studies have indicated that both UCP1 ablation (Winn et al. 2017b) and OVX (Nickelson et al. 2012, Pettersson et al. 2012, Vieira Potter et al. 2012) induce insulin resistance, this is the first time, to our knowledge, that synergistic effects of UCP1 ablation and OVX on insulin resistance have been demonstrated. These findings are important in light of the fact that aging reduces UCP1 in both sexes (Yamashita et al. 1999, Yoneshiro et al. 2013). Thus, age-related reductions in UCP1 may contribute to sex differences in age-related metabolic impairments, since women are affected by aging and ovarian hormone loss. It is also noteworthy that genetic mutations in genes that regulate UCP1 have been associated with longevity in humans (Yoneshiro et al. 2013); thus, genetic differences in UCP1 expression may make some women more or less susceptible to menopause-associated metabolic dysfunction. 
Adipose tissue inflammation has been shown to induce insulin resistance (Gutierrez et al. 2009), and we previously demonstrated that adipose tissue inflammation occurs independent of adiposity increase and precedes insulin resistance following OVX in mice (Vieira Potter et al. 2012). However, our present findings do not indicate elevated adipose tissue inflammation caused the exacerbated impairment in OVX-induced insulin resistance in UCP1KO mice. It was somewhat surprising that both OVX and UCP1 ablation led to increases in circulating adiponectin. The increased adiponectin levels in the $\mathrm{KO}$ and OVX groups is counter-intuitive, since adiponectin is insulin sensitizing (Berg et al. 2001, Fruebis et al. 2001, Yamauchi et al. 2001). However, most studies looking at adiponectin as it relates to obesity (for example) have been conducted in male rodents. Indeed, females have a greater \% body fat, better adipocyte insulin sensitivity, greater adiponectin levels and have been shown to increase adiponectin despite greater adiposity (Kern et al. 2003). Another study in rats (Garcia-Carrizo et al. 2017) showed adiponectin to decrease with obesity in males but not females, which associated with greater metabolic protection among the females. Importantly, the leptin-to-adiponectin ratio was not different between WT and KO mice and was increased with OVX in both genotypes. The lack of robust differences in insulin sensitivity among the groups studied here, all fed normal low-fat rodent chow diet, could be due to the compensatory role of adiponectin.

Mechanistically, it is unclear why the UCP1-null animals were more susceptible to OVX-induced insulin resistance. The mechanism does not appear to involve changes in adipose tissue $E_{2}$ receptor expression, which has been associated with insulin resistance (Lizcano \& Guzmán 2014). Nor do our data support that UCP1 protected mice from OVX-induced adipose tissue inflammation. A limitation to this study is that BAT lipid content was not quantified, although histological examination of BAT indicated subtle OVX-induced 'whitening', which was supported by increased leptin gene expression and larger interscapular and periaortic BAT depot weights. However, those changes were not apparently exacerbated in UCP1KO animals. The UCP1KO did have reduced BAT mitochondrial protein content (e.g., electron transport chain proteins COX 1, 2, and 4) suggestive of BAT whitening, consistent with our previous studies (Winn et al. 2017a,b). UCP1 protein is vital for mitochondrial integrity and function, as ablation has been shown to reduce mitochondrial content and render mitochondria susceptible to reactive oxygen species-induced permeability (Kazak et al. 2017). Indeed, UCP1 activity reduces oxidative stress and improves mitochondrial function (Shabalina et al. 2006, Oelkrug et al. 2010, Stier et al. 2014). Consistently, BAT gene expression levels of Ddit3 and Fgf21, indicative of cellular stress, were significantly increased in UCP1KO mice. Although direct mitochondrial energetic assessments were not performed, our observations of reduced mitochondrial content may suggest that the UCP1KO animals had impaired mitochondrial function. Paradoxically, gene expression of the marker of mitochondrial biogenesis, Tfam was actually increased in UCP1KO. This may also be indicative of less functional mitochondria in adipose tissue of UCP1KO animals (Nadal-Casellas et al. 2011). Since OVX is known to increase oxidative stress, we hypothesized that UCP1KO animals would develop greater inflammation following OVX compared to WT. We did not find this to be true, but we did find that UCP1KO animals had increased susceptibility to OVX-induced suppression of $G p \times 3$. Thus, it is probable that, under more adverse metabolic conditions (e.g., high-fat diet, aging), greater divergence in responsiveness to OVX between WT and $\mathrm{KO}$ animals would be observed.

It is critical that the findings presented here are appreciated with awareness of the import impact that environmental temperature may have had on the findings. That is, this study was conducted close to, or just below thermoneutrality. Previous studies have confirmed that the metabolic effects of UCP1 ablation differ significantly under different environmental temperature conditions (von Essen et al. 2017). Thus, an important future direction is to compare the results of the present study to those obtained when mice are housed at warmer (and colder) temperatures. Temperature-specific differences observed in how UCP1 and OVX interact may lend mechanistic insight into the relationship between ovarian hormones and UCP1.

In summary, it is apparent that ovarian hormones and UCP1 both play an integral role in the preservation of metabolic health in females. In this study, we have shown that loss of ovarian-derived hormones and UCP1 ablation cause synergistic detriment to glucose metabolism, resulting in more severe insulin resistance than either UCP1 ablation or OVX alone. Further studies are needed to examine the potential mechanistic relationships between $\mathrm{E}_{2}$ signaling and UCP1, and how their interactions may influence metabolic health. Nonetheless, our current findings suggest that UCP1 is an important candidate protein that may interact with $\mathrm{E}_{2}$ to mediate protective effects. Most important, these findings point to UCP1 as a potential therapeutic target for postmenopausal metabolic dysfunction. 


\section{Supplementary data}

This is linked to the online version of the paper at https://doi.org/10.1530/ JOE-18-0139.

\section{Declaration of interest}

The authors declare that there is no conflict of interest that could be perceived as prejudicing the impartiality of the research reported.

\section{Funding}

This study was supported in part by grants from the University of Missouri (Ryo et al.) Research Council (V J Vieira-Potter), MU Richard Wallace Faculty Incentive Grant (V J Vieira-Potter), Cardiometabolic Disease Research Foundation (J Padilla), Sears Trust Research Foundation (J Padilla), and National Institutes of Health K01-HL-125503 (J Padilla).

\section{Author contribution statement}

$S L C, R J W, M L W, T M Z, M L G, Z$ I G, N C W and D E performed experiments; S L C, R J W and V V P analyzed data; S L C, V V P, N C W and $J$ J interpreted results; $S L C$ and N C W prepared figures; $S L C$ drafted the manuscript; S L C, R J W, T M Z, M L G, M L W, Z I G, N C W, D E, J P, V V P, N G K and H S S edited and revised manuscript; $S L C, R J W, T M Z, M L G$, $M L W, Z$ I G, N C W, D E, J P, V V P, N G K and H S S approved final version of the manuscript; H S S, J P and V V P conceived and designed research.

\section{References}

Al-Qahtani SM, Bryzgalova G, Valladolid-Acebes I, Korach-André M, Dahlman-Wright K, Efendić S, Berggren P-O \& Portwood N 2017 $17 \beta$-Estradiol suppresses visceral adipogenesis and activates brown adipose tissue-specific gene expression. Hormone Molecular Biology and Clinical Investigation 29 13-26. (https://doi.org/10.1515/hmbci-20160031)

Antunes LC, Elkfury JL, Jornada MN, Foletto KC \& Bertoluci MC 2016 Validation of HOMA-IR in a model of insulin-resistance induced by a high-fat diet in Wistar rats. Archives of Endocrinology and Metabolism 60 138-142. (https://doi.org/10.1590/2359-3997000000169)

Auro K, Joensuu A, Fischer K, Kettunen J, Salo P, Mattsson H, Niironen M, Kaprio J, Eriksson JG, Lehtimäki T, et al. 2014 A metabolic view on menopause and ageing. Nature Communications 5 4708. (https://doi. org/10.1038/ncomms5708)

Berg AH, Combs TP, Du X, Brownlee M \& Scherer PE 2001 The adipocytesecreted protein Acrp30 enhances hepatic insulin action. Nature Medicine 7 947-953. (https://doi.org/10.1038/90992)

Cannon B \& Nedergaard J 2010 Metabolic consequences of the presence or absence of the thermogenic capacity of brown adipose tissue in mice (and probably in humans). International Journal of Obesity $\mathbf{3 4}$ S7-S16. (https://doi.org/10.1038/ijo.2010.177)

Chondronikola M, Volpi E, Børsheim E, Porter C, Annamalai P, Enerbäck S, Lidell ME, Saraf MK, Labbe SM, Hurren NM, et al. 2014 Brown adipose tissue improves whole-body glucose homeostasis and insulin sensitivity in humans. Diabetes 63 4089-4099. (https://doi. org/10.2337/db14-0746)

Crissey JM, Jenkins NT, Lansford KA, Thorne PK, Bayless DS, VieiraPotter VJ, Rector RS, Thyfault JP, Laughlin MH \& Padilla J 2014 Adipose tissue and vascular phenotypic modulation by voluntary physical activity and dietary restriction in obese insulin-resistant
OLETF rats. American Journal of Physiology: Regulatory, Integrative and Comparative Physiology 306 R596-R606. (https://doi.org/10.1152/ ajpregu.00493.2013)

Cypess AM, Lehman S, Williams G, Tal I, Rodman D, Goldfine AB, Kuo FC, Palmer EL, Tseng YH, Doria A, et al. 2009 Identification and importance of brown adipose tissue in adult humans. New England Journal of Medicine 360 1509-1517. (https://doi.org/10.1056/ NEJMoa0810780)

de Morentin PBM, González-García I, Martins L, Lage R, FernándezMallo D, Martínez-Sánchez N, Ruíz-Pino F, Liu J, Morgan DA, Pinilla L, et al. 2014 Estradiol regulates brown adipose tissue thermogenesis via hypothalamic AMPK. Cell Metabolism 20 41-53. (https://doi.org/10.1016/j.cmet.2014.03.031)

Digby JE, Montague CT, Sewter CP, Sanders L, Wilkison WO, O'rahilly S \& Prins JB 1998 Thiazolidinedione exposure increases the expression of uncoupling protein 1 in cultured human preadipocytes. Diabetes $\mathbf{4 7}$ $138-141$.

Drew BG, Hamidi H, Zhou Z, Villanueva CJ, Krum SA, Calkin AC, Parks BW, Ribas V, Kalajian NY, Phun J, et al. 2015 Estrogen receptor (ER)alpha-regulated lipocalin 2 expression in adipose tissue links obesity with breast cancer progression. Journal of Biological Chemistry 290 5566-5581. (https://doi.org/10.1074/jbc.M114.606459)

Feldmann HM, Golozoubova V, Cannon B \& Nedergaard J 2009 UCP1 ablation induces obesity and abolishes diet-induced thermogenesis in mice exempt from thermal stress by living at thermoneutrality. Cell Metabolism 9 203-209. (https://doi.org/10.1016/j.cmet.2008.12.014)

Frank AP, Palmer BF \& Clegg DJ 2017. Do estrogens enhance activation of brown and beiging of adipose tissues? Physiology and Behavior 187 24-31. (https://doi.org/10.1016/j.physbeh.2017.09.026)

Fruebis J, Tsao T-S, Javorschi S, Ebbets-Reed D, Erickson MRS, Yen FT, Bihain BE \& Lodish HF 2001 Proteolytic cleavage product of 30-kDa adipocyte complement-related protein increases fatty acid oxidation in muscle and causes weight loss in mice. PNAS 98 2005-2010. (https://doi.org/10.1073/pnas.041591798)

Gambacciani M, Ciaponi M, Cappagli B, Piaggesi L, De Simone L, Orlandi R \& Genazzani A 1997 Body weight, body fat distribution, and hormonal replacement therapy in early postmenopausal women. Journal of Clinical Endocrinology and Metabolism 82 414-417. (https:// doi.org/10.1210/jcem.82.2.3735)

Gao H \& Dahlman-Wright K 2013 Implications of estrogen receptor alpha and estrogen receptor beta for adipose tissue functions and cardiometabolic complications. Hormone Molecular Biology and Clinical Investigation 15 81-90. (https://doi.org/10.1515/hmbci-2013-0021)

Garcia-Carrizo F, Priego T, Szostaczuk N, Palou A \& Picó C 2017 Sexual dimorphism in the age-induced insulin resistance, liver steatosis, and adipose tissue function in rats. Frontiers in Physiology 8 445. (https:// doi.org/10.3389/fphys.2017.00445)

Ginsberg HN \& MacCallum PR 2009 The obesity, metabolic syndrome, and type 2 diabetes mellitus pandemic: part I. Increased cardiovascular disease risk and the importance of atherogenic dyslipidemia in persons with the metabolic syndrome and type 2 diabetes mellitus. Journal of the Cardiometabolic Syndrome 4 113-119. (https://doi.org/10.1111/j.1559-4572.2008.00044.x)

Gonçalves LF, Machado TQ, Castro-Pinheiro C, Souza NG, Oliveira KJ \& Fernandes-Santos C 2017 Ageing is associated with brown adipose tissue remodelling and loss of white fat browning in female C57BL/6 mice. International Journal of Experimental Pathology 98 100-108. (https://doi.org/10.1111/iep.12228)

Grefhorst A, van den Beukel JC, van Houten EL, Steenbergen J, Visser JA $\&$ Themmen AP 2015 Estrogens increase expression of bone morphogenetic protein $8 \mathrm{~b}$ in brown adipose tissue of mice. Biology of Sex Differences 6 7. (https://doi.org/10.1186/s13293-015-0025-y)

Gutierrez DA, Puglisi MJ \& Hasty AH 2009 Impact of increased adipose tissue mass on inflammation, insulin resistance, and dyslipidemia. Current Diabetes Reports 9 26-32. (https://doi.org/10.1007/s11892-0090006-9) (c) 2018 Society for Endocrinology Published by Bioscientifica Ltd. Printed in Great Britain 
Ikeda K, Kang Q, Yoneshiro T, Camporez JP, Maki H, Homma M, Shinoda K, Chen Y, Lu X, Maretich P, et al. 2017 UCP1-independent signaling involving SERCA2b-mediated calcium cycling regulates beige fat thermogenesis and systemic glucose homeostasis. Nature Medicine 23 1454-1465. (https://doi.org/10.1038/nm.4429)

Kanda H, Tateya S, Tamori Y, Kotani K, Hiasa K-i, Kitazawa R, Kitazawa S, Miyachi H, Maeda S, Egashira K, et al. 2006 MCP-1 contributes to macrophage infiltration into adipose tissue, insulin resistance, and hepatic steatosis in obesity. Journal of Clinical Investigation 116 1494-1505. (https://doi.org/10.1172/JCI26498)

Kazak L, Chouchani ET, Stavrovskaya IG, Lu GZ, Jedrychowski MP, Egan DF, Kumari M, Kong X, Erickson BK, Szpyt J, et al. 2017 UCP1 deficiency causes brown fat respiratory chain depletion and sensitizes mitochondria to calcium overload-induced dysfunction. PNAS 114 7981-7986. (https://doi.org/10.1073/pnas.1705406114)

Kern PA, Di Gregorio GB, Lu T, Rassouli N \& Ranganathan G 2003 Adiponectin expression from human adipose tissue: relation to obesity, insulin resistance, and tumor necrosis factor- $\alpha$ expression. Diabetes 52 1779-1785. (https://doi.org/10.2337/ diabetes.52.7.1779)

Kopecky J, Rossmeisl M, Hodny Z, Syrovy I, Horakova M \& Kolarova P 1996 Reduction of dietary obesity in aP2-Ucp transgenic mice: mechanism and adipose tissue morphology. American Journal of Physiology: Endocrinology and Metabolism 270 E776-E786. (https://doi. org/10.1152/ajpendo.1996.270.5.E776)

Lizcano F \& Guzmán G 2014 Estrogen deficiency and the origin of obesity during menopause. BioMed Research International 2014 757461. (https://doi.org/10.1155/2014/757461)

Lomonaco R, Ortiz-Lopez C, Orsak B, Webb A, Hardies J, Darland C, Finch J, Gastaldelli A, Harrison S, Tio F, et al. 2012 Effect of adipose tissue insulin resistance on metabolic parameters and liver histology in obese patients with nonalcoholic fatty liver disease. Hepatology $\mathbf{5 5}$ 1389-1397. (https://doi.org/10.1002/hep.25539)

Lundholm L, Putnik M, Otsuki M, Andersson S, Ohlsson C, Gustafsson JA \& Dahlman-Wright K 2008 Effects of estrogen on gene expression profiles in mouse hypothalamus and white adipose tissue: target genes include glutathione peroxidase 3 and cell death-inducing DNA fragmentation factor, alpha-subunit-like effector A. Journal of Endocrinology 196 547-557. (https://doi.org/10.1677/JOE-07-0277)

Manolopoulos K, Karpe F \& Frayn K 2010 Gluteofemoral body fat as a determinant of metabolic health. International Journal of Obesity $\mathbf{3 4}$ 949-959. (https://doi.org/10.1038/ijo.2009.286)

Matthews DR, Hosker JP, Rudenski AS, Naylor BA, Treacher DF \& Turner RC 1985 Homeostasis model assessment: insulin resistance and beta-cell function from fasting plasma glucose and insulin concentrations in man. Diabetologia 28 412-419. (https://doi. org/10.1007/BF00280883)

Nadal-Casellas A, Proenza AM, Lladó I \& Gianotti M 2011 Effects of ovariectomy and $17-\beta$ estradiol replacement on rat brown adipose tissue mitochondrial function. Steroids 76 1051-1056. (https://doi. org/10.1016/j.steroids.2011.04.009)

Nickelson KJ, Stromsdorfer KL, Pickering RT, Liu T-W, Ortinau LC, Keating AF \& Perfield JW 2012 A comparison of inflammatory and oxidative stress markers in adipose tissue from weight-matched obese male and female mice. Experimental Diabetes Research 2012859395. (https://doi.org/10.1155/2012/859395)

Nookaew I, Svensson PA, Jacobson P, Jernas M, Taube M, Larsson I, Andersson-Assarsson JC, Sjostrom L, Froguel P, Walley A, et al. 2013 Adipose tissue resting energy expenditure and expression of genes involved in mitochondrial function are higher in women than in men. Journal of Clinical Endocrinology and Metabolism 98 E370-E378. (https://doi.org/10.1210/jc.2012-2764)

Oelkrug R, Kutschke M, Meyer CW, Heldmaier G \& Jastroch M 2010 Uncoupling protein 1 decreases superoxide production in brown adipose tissue mitochondria. Journal of Biological Chemistry 285 21961-21968. (https://doi.org/10.1074/jbc.M110.122861)
Ouellet V, Routhier-Labadie A, Bellemare W, Lakhal-Chaieb L, Turcotte E, Carpentier AC \& Richard D 2011 Outdoor temperature, age, sex, body mass index, and diabetic status determine the prevalence, mass, and glucose-uptake activity of 18F-FDG-detected BAT in humans. Journal of Clinical Endocrinology and Metabolism 96 192-199. (https://doi. org/10.1210/jc.2010-0989)

Ouyang P, Michos ED \& Karas RH 2006 Hormone replacement therapy and the cardiovascular system: lessons learned and unanswered questions. Journal of the American College of Cardiology 47 1741-1753. (https://doi.org/10.1016/j.jacc.2005.10.076)

Padilla J, Jenkins NT, Roberts MD, Arce-Esquivel AA, Martin JS, Laughlin MH \& Booth FW 2013 Differential changes in vascular mRNA levels between rat iliac and renal arteries produced by cessation of voluntary running. Experimental Physiology 98 337-347. (https://doi.org/10.1113/expphysiol.2012.066076)

Park Y-M, Kanaley JA, Padilla J, Zidon T, Welly RJ, Will MJ, Britton SL, Koch LG, Ruegsegger GN, Booth FW, et al. 2016 Effects of intrinsic aerobic capacity and ovariectomy on voluntary wheel running and nucleus accumbens dopamine receptor gene expression. Physiology and Behavior 164 383-389. (https://doi.org/10.1016/j. physbeh.2016.06.006)

Park YM, Pereira RI, Erickson CB, Swibas TA, Cox-York KA \& Van Pelt RE 2017 Estradiol-mediated improvements in adipose tissue insulin sensitivity are related to the balance of adipose tissue estrogen receptor alpha and beta in postmenopausal women. PLOS ONE 12 e0176446. (https://doi.org/10.1371/journal.pone.0176446)

Pedersen SB, Bruun JM, Kristensen K \& Richelsen B 2001 Regulation of UCP1, UCP2, and UCP3 mRNA expression in brown adipose tissue, white adipose tissue, and skeletal muscle in rats by estrogen. Biochemical and Biophysical Research Communications 288 191-197. (https://doi.org/10.1006/bbrc.2001.5763)

Pettersson US, Waldén TB, Carlsson P-O, Jansson L \& Phillipson M 2012 Female mice are protected against high-fat diet induced metabolic syndrome and increase the regulatory $\mathrm{T}$ cell population in adipose tissue. PLOS ONE 7 e46057. (https://doi.org/10.1371/journal.pone.0046057)

Pfannenberg C, Werner MK, Ripkens S, Stef I, Deckert A, Schmadl M, Reimold M, Häring H-U, Claussen CD \& Stefan N 2010 Impact of age on the relationships of brown adipose tissue with sex and adiposity in humans. Diabetes 59 1789-1793. (https://doi.org/10.2337/db10-0004)

Poher A-L, Veyrat-Durebex C, Altirriba J, Montet X, Colin DJ, Caillon A, Lyautey J \& Rohner-Jeanrenaud F 2015 Ectopic UCP1 overexpression in white adipose tissue improves insulin sensitivity in Lou/C Rats, a Model of Obesity Resistance Lou. Diabetes 64 3700-3712. (https://doi. org/10.2337/db15-0210)

Qian S-w, Liu Y, Wang J, Nie J-C, Wu M-y, Tang Y, Zhao Y-X, Li X, Huang H-y, Guo L, et al. 2016 BMP4 cross-talks with estrogen/ $\mathrm{ER} \alpha$ signaling to regulate adiposity and glucose metabolism in females. EBioMedicine 11 91-100. (https://doi.org/10.1016/j. ebiom.2016.07.034)

Quevedo S, Roca P, Picó C \& Palou A 1998 Sex-associated differences in cold-induced UCP1 synthesis in rodent brown adipose tissue. Pflügers Archiv: European Journal of Physiology 436 689-695. (https://doi. org/10.1007/s004240050690)

Reaven GM 2011 Insulin resistance: the link between obesity and cardiovascular disease. Medical Clinics of North America 95 875-892. (https://doi.org/10.1016/j.mcna.2011.06.002)

Regensteiner JG, Golden S, Huebschmann AG, Barrett-Connor E, Chang AY, Chyun D, Fox CS, Kim C, Mehta N, Reckelhoff JF, et al. 2015 Sex differences in the cardiovascular consequences of diabetes mellitus: a Scientific Statement From the American Heart Association. Circulation 132 2424-2447. (https://doi.org/10.1161/ CIR.0000000000000343)

Rogers NH, Perfield JW 2nd, Strissel KJ, Obin MS \& Greenberg AS 2009 Reduced energy expenditure and increased inflammation are early events in the development of ovariectomy-induced obesity. Endocrinology 150 2161-2168. (https://doi.org/10.1210/en.2008-1405) (c) 2018 Society for Endocrinology Published by Bioscientifica Ltd. Printed in Great Britain 
Roseguini BT, Mehmet Soylu S, Whyte JJ, Yang HT, Newcomer S \& Laughlin MH 2010 Intermittent pneumatic leg compressions acutely upregulate VEGF and MCP-1 expression in skeletal muscle. American Journal of Physiology: Heart and Circulatory Physiology 298 H1991-2000. (https://doi.org/10.1152/ajpheart.00006.2010)

Ryo M, Nakamura T, Kihara S, Kumada M, Shibazaki S, Takahashi M, Nagai M, Matsuzawa Y \& Funahashi T 2004 Adiponectin as a biomarker of the metabolic syndrome. Circulation Journal 68 975-981. (https://doi.org/10.1253/circj.68.975)

Sakamoto T, Nitta T, Maruno K, Yeh Y-S, Kuwata H, Tomita K, Goto T, Takahashi N \& Kawada T 2016 Macrophage infiltration into obese adipose tissues suppresses the induction of UCP1 level in mice. American Journal of Physiology: Endocrinology and Metabolism $\mathbf{3 1 0}$ E676-E687. (https://doi.org/10.1152/ajpendo.00028.2015)

Shabalina IG, Petrovic N, Kramarova TV, Hoeks J, Cannon B \& Nedergaard J 2006 UCP1 and defense against oxidative stress 4-hydroxy-2-nonenal effects on brown fat mitochondria are uncoupling protein 1-independent. Journal of Biological Chemistry 281 13882-13893. (https://doi.org/10.1074/jbc.M601387200)

Stanford KI, Middelbeek RJ, Townsend KL, An D, Nygaard EB, Hitchcox KM, Markan KR, Nakano K, Hirshman MF, Tseng Y-H, et al. 2012 Brown adipose tissue regulates glucose homeostasis and insulin sensitivity. Journal of Clinical Investigation 123 215-223. (https://doi. org/10.1172/JCI62308)

Stefanska A, Bergmann K \& Sypniewska G 2015 Metabolic syndrome and menopause: pathophysiology, clinical and diagnostic significance. Advances in Clinical Chemistry 72 1-75. (https://doi.org/10.1016/ bs.acc.2015.07.001)

Stier A, Bize P, Habold C, Bouillaud F, Massemin S \& Criscuolo F 2014 Mitochondrial uncoupling prevents cold-induced oxidative stress: a case study using UCP1 knockout mice. Journal of Experimental Biology 217 624-630. (https://doi.org/10.1242/jeb.092700)

van den Beukel JC, Grefhorst A, Hoogduijn MJ, Steenbergen J, Mastroberardino PG, Dor FJ \& Themmen AP 2015 Women have more potential to induce browning of perirenal adipose tissue than men. Obesity 23 1671-1679. (https://doi.org/10.1002/oby.21166)

van der Lans AA, Hoeks J, Brans B, Vijgen GH, Visser MG, Vosselman MJ, Hansen J, Jorgensen JA, Wu J, Mottaghy FM, et al. 2013 Cold acclimation recruits human brown fat and increases nonshivering thermogenesis. Journal of Clinical Investigation 123 3395-3403. (https://doi.org/10.1172/JCI68993)

Vieira-Potter VJ 2014 Inflammation and macrophage modulation in adipose tissues. Cellular Microbiology 16 1484-1492. (https://doi. org/10.1111/cmi.12336)

Vieira Potter VJ, Strissel KJ, Xie C, Chang E, Bennett G, Defuria J, Obin MS \& Greenberg AS 2012 Adipose tissue inflammation and reduced insulin sensitivity in ovariectomized mice occurs in the absence of increased adiposity. Endocrinology 153 4266-4277. (https:// doi.org/10.1210/en.2011-2006)

Vieira-Potter VJ, Padilla J, Park Y-M, Welly RJ, Scroggins RJ, Britton SL, Koch LG, Jenkins NT, Crissey JM, Zidon T, et al. 2015 Female rats selectively bred for high intrinsic aerobic fitness are protected from ovariectomy-associated metabolic dysfunction. American Journal of Physiology: Regulatory, Integrative and Comparative Physiology $\mathbf{3 0 8}$ R530-R542. (https://doi.org/10.1152/ajpregu.00401.2014) von Essen G, Lindsund E, Cannon B \& Nedergaard J 2017 Adaptive facultative diet-induced thermogenesis in wild-type but not in UCP1-ablated mice. American Journal of Physiology: Endocrinology and Metabolism 313 E515-E527. (https://doi.org/10.1152/ ajpendo.00097.2017)

Wainright KS, Fleming NJ, Rowles JL, Welly RJ, Zidon TM, Park YM, Gaines TL, Scroggins RJ, Anderson-Baucum EK, Hasty AH, et al. 2015 Retention of sedentary obese visceral white adipose tissue phenotype with intermittent physical activity despite reduced adiposity. American Journal of Physiology: Regulatory Integrative and Comparative Physiology 309 R594-R602. (https://doi.org/10.1152/ajpregu.00042.2015)

Waldén TB, Hansen IR, Timmons JA, Cannon B \& Nedergaard J 2011 Recruited vs. nonrecruited molecular signatures of brown, 'brite,' and white adipose tissues. American Journal of Physiology: Endocrinology and Metabolism 302 E19-E31. (https://doi.org/10.1152/ ajpendo.00249.2011)

Wang Q, Zhang M, Xu M, Gu W, Xi Y, Qi L, Li B \& Wang W 2015 Brown adipose tissue activation is inversely related to central obesity and metabolic parameters in adult human. PLOS ONE 10 e0123795. (https://doi.org/10.1371/journal.pone.0123795)

Winn NC, Grunewald ZI, Gastecki ML, Woodford ML, Welly RJ, Clookey SL, Ball JR, Gaines TKL, Karasseva NG, Kanaley JA, et al. $2017 a$ Deletion of UCP1 enhances ex vivo aortic vasomotor function in female but not male mice despite similar susceptibility to metabolic dysfunction. American Journal of Physiology: Endocrinology and Metabolism 313 E402-E412. (https://doi.org/10.1152/ ajpendo.00096.2017)

Winn NC, Vieira-Potter VJ, Gastecki ML, Welly RJ, Scroggins RJ, Zidon TM, Gaines TL, Woodford ML, Karasseva NG, Kanaley JA, et al. 2017b Loss of UCP1 exacerbates Western diet-induced glycemic dysregulation independent of changes in body weight in female mice. American Journal of Physiology: Regulatory Integrative and Comparative Physiology 312 R74-R84. (https://doi.org/10.1152/ajpregu.00425.2016)

Yamashita H, Sato Y \& Mori N 1999 Difference in induction of uncoupling protein genes in adipose tissues between young and old rats during cold exposure. FEBS Letters 458 157-161. (https://doi org/10.1016/S0014-5793(99)01143-6)

Yamauchi T, Kamon J, Waki H, Terauchi Y, Kubota N, Hara K, Mori Y, Ide T, Murakami K, Tsuboyama-Kasaoka N, et al. 2001 The fat-derived hormone adiponectin reverses insulin resistance associated with both lipoatrophy and obesity. Nature Medicine 7 941-946. (https://doi. org/10.1038/90984)

Yao L, Heuser-Baker J, Herlea-Pana O, Zhang N, Szweda LI, Griffin TM \& Barlic-Dicen J 2014 Deficiency in adipocyte chemokine receptor CXCR4 exacerbates obesity and compromises thermoregulatory responses of brown adipose tissue in a mouse model of diet-induced obesity. FASEB Journal 28 4534-4550. (https://doi.org/10.1096/fj.14249797)

Yasrebi A, Rivera JA, Krumm EA, Yang JA \& Roepke TA 2016 Activation of estrogen response element-independent ER $\alpha$ signaling protects female mice from diet-induced obesity. Endocrinology 158 319-334.

Yoneshiro T, Ogawa T, Okamoto N, Matsushita M, Aita S, Kameya T, Kawai Y, Iwanaga T \& Saito M 2013 Impact of UCP1 and beta3AR gene polymorphisms on age-related changes in brown adipose tissue and adiposity in humans. International Journal of Obesity 37 993-998.

Received in final form 30 July 2018

Accepted 6 August 2018

Accepted Preprint published online 8 August 2018 https://joe.bioscientifica.com https://doi.org/10.1530/JOE-18-0139 (c) 2018 Society for Endocrinology Published by Bioscientifica Ltd. Printed in Great Britain 